The pedicell. gemmiformes have the same function, and in grasping they are assisted by the secretion in the glandular sacs of the valves, as experiment shows. In Echinus microtuberculatus the glandbearing pedicellariæ stand chiefly on the dorsal surface and serve, as I have been able to ascertain from many animals kept in the aquarium, to hold fast fronds of seaweeds \&c. with which the seaurchin masks itself both when at rest and when in motion. In this the slimy secretion of its glandular pedicellariæ is of the greatest service.-Sitzungsberichte der Jenaischen Gesellschaft für Medicin und Naturwissenschaft, 1886.

\title{
Discovery of the Heart in Gamasus.
}

\section{To the Editors of the 'Annals and Magazine of Natural History.'}

Gentlemen,-My attention has just been called to a translation in your February number of Prof. C. Claus's paper in the 'Anzeiger' of the Academy of Vienna relative to Herr Willibald Winkler's supposed discovery of the heart in Gamasus. If Prof. Claus and Herr Winkler imagine that the latter has observed this organ for the first time they are in error. It was noticed in 1876 by Dr. P. Kramer, then of Schleusingen, who published his remarks on the subject in the Archiv für Naturg. xlii. Jahrg. $1 \mathrm{Bd}$. p. 65 , as one paragraph of a paper entitled "Zur Naturg. einiger Gattungen aus d. Familie d. Gamasiden." The paragraph is as follows :-

"Das Circulationsorgan. Bei Gamasus findet sich endlich im letzten Drittel des Hinterleibes ein lebhaft pulsirendes Herz. Da bei den meisten Arten die verhärtete Rückendecke die Beobachtung der innern Organe unmöglich macht, so eignen sich zur Auffindung des Herzens nur unerwachsene oder eben durch eine Häutung gegangene Thiere, an denen es aber leicht und sicher erkannt werden kann. Seine Bewegungen sind von denen der Excretionsdrüse natürlich auf das bestimmteste verschieden, auch entspricht seine Lage ganz dicht unter der Haut der Lage desselben Organs bei andern Gliederthieren."

Dr. Kramer's observation is perfectly well known amongst Acarologists and has been publicly referred to by Dr. Haller, myself, and others in our writings. It will be seen that Dr. Kramer did not describe the valves, and it is perhaps fair to say that in some quarters doubts have been entertained whether the organ really was a heart or whether the movement was not more allied to the strong, presumably peristaltic, movements which may be observed in the eæca of the alimentary canal in young Gamasids. If Herr Winkler's observation of the valves be reliable it will, of course, strongly confirm Dr. Kramer's discovery.

Prof. Claus may possibly not find it so easy to trace the organ in other families of the Acarina, as, judging from his remarks, he may very naturally anticipate; at all events, I am not aware that it has hitherto been traced in any other, although, as above stated, Kramer's observation has been well known for several years.

\section{I am, yours obediently,}

Cadogan Mansions, Sloane Square, Albert D. Michael. April 17, 1886. 


\section{$2 \mathrm{BHL}$ Biodiversity Heritage Library}

1886. "Discovery of the heart in Gamasus." The Annals and magazine of natural history; zoology, botany, and geology 17, 472-472.

https://doi.org/10.1080/00222938609460176.

View This Item Online: $\underline{\text { https://www.biodiversitylibrary.org/item/53478 }}$

DOI: https://doi.org/10.1080/00222938609460176

Permalink: https://www.biodiversitylibrary.org/partpdf/52299

\section{Holding Institution}

Smithsonian Libraries

\section{Sponsored by}

Smithsonian

\section{Copyright \& Reuse}

Copyright Status: Public domain. The BHL considers that this work is no longer under copyright protection.

This document was created from content at the Biodiversity Heritage Library, the world's largest open access digital library for biodiversity literature and archives. Visit BHL at https://www.biodiversitylibrary.org. 